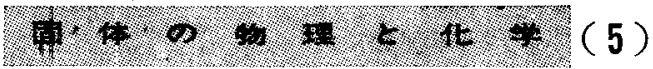

電導現象と半導体 (その 2)

長船, 広 衛*

前回は固体の電導現象一般の立場から言真の問題とし て固体内の電子の持つエネルギの带域構造を取り上げた が，今回は半導体での問題点を取り扱いたい。

\section{5. 半道体の電導現象}

带域論の立場からは金属と絶縁物との囚別を明確にで き，半導体は本質的には絶縁物の一種であることはすで に述べた. 半導体の電導現象で特に注目すべきるのは次 の性質であるう。

（1）比抵抗の負性温度係数，（2）特性の棈造感性, 微 量の不純物, 結晶性, (3) 正負 2 種類のキょリア（ホー 儿係数), (4) 整流現像, (5) 光電緮, (6) 光起霓力, (7) 熱電現象

「半導体」といら言葉は現在非常に広義に使用されて いるが，こ」では一応代表的なるのとしで゙ルマニウム やシリコンのような共有結合結晶に限る。これらはトラ ンジスタや整流器など工業的価值も高いばかりでなく， 電子の状態に対する矿究が最死進んでいる。そこでこの 種の半導体に対するモデルと上記の半導体特有の性質と の関連要述べよう.

\section{1 真性 (固有) 半導体}

エネルギの帯域モデルは波動力学から出発した結論で 信頼できるがいささか抽象的に過ぎ，かかりにくい，々 こで平素われわれが报いなれた原子や電子などの粒子モ デルとの関連性を求める.ゲルマニウムの結晶はダイヤ モンド格子で最隣接原子は4つあり，磷接した原子とそ れぞれ1個づつ電子を出し合っていかゆる共有結合をし ていて，中心的草イオンがある. 各原子は最外部の 4 個の電子を結合すなわち原子洒電子として用い，結合 の様子は図7 (a) のようになり, 最上位の完充帯を形成 すると考光る. 理想的な完全結晶なら当然完充带は完全

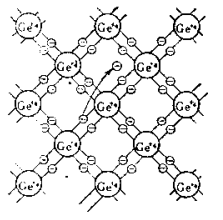

(a) 粒子モデル

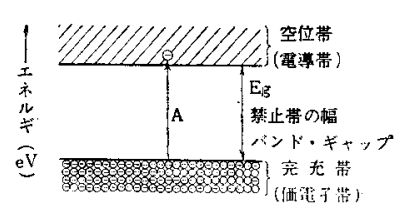

(b) 带域モデル
図 7 真性半導体のモデル
に電子で渾され，禁止带を隔て小空位带がその上にある はずで，带域モデルでは図7(b) のようになる。このま 」の状態では電子が加速されないから絶縁物である.

絶縁物の状態はしかし絶刘零度でしか実現しない.す なわち有限の温度では当然熱覺乱によってかる割合の電 子は完允電のすぐ上の空位带移るはずで，その割合は 温度己禁止帯の幅（バンド・ギャップ） $E_{g}$ できまる。 温度が高いほど， $E_{g}$ が小さいほど空位帯に移る電子の 密度すなわちキャリア濃度は高くなり, 電㰾度が上る. こょで半導体と絶縁物との相違は本䆩的なるのではな く， $E_{g}$ の大小で, 常温に括いて熱的に発生したキャり アによってめる程度の電導度を持つかどうかで漠然と区 別しているに過ざない，次にダィヤモンド格子を持つIV 族の結晶の禁止帯の幅を示そう。

\begin{tabular}{|c|c|c|c|c|}
\hline 結＼cjkstart晶 & ダイヤモンド & シリコン & ゲルマニウム & 扊色スズ \\
\hline 禁止帯の幅 & $6 \sim 7 \mathrm{eV}$ & $1.11 \mathrm{eV}$ & $0.72 \mathrm{eV}$ & $0.1 \mathrm{eV}$ \\
\hline
\end{tabular}

これからダィヤモンドは常温で絶縁物, シリコンとゲ ルマニウムは半導体，灰色スズは本質的には半導体であ るが常温ではほとんど金属汇近い性暂を持ち，非常に低 温で半導体の性質を示すので半金属と呼ぶ場合もある. さらにこれらの元素の中間にある $\mathrm{SiC}$ (炭化ヶィ素) や $\mathrm{Si}$ 之 $\mathrm{Ge}$ の合金はそれぞれの $E_{g}$ の中間值をとること は興味深いことである。

ところで $\mathrm{Ge}^{+4}-\mathrm{Ge}^{+4}$ の結合にあずかる価電子が最上 部の完充帯を形成しているので，この完充帯を特に価電 子帯 (valence band) と呼び, そのすぐ上の空位帯はそ こに電子がくると電導に役立つので電導带 (conduction band)と呼び, 普通半導体で問題になるのはこの $2 つ の$ 許容帯だけである. A温度が上って熱䚌乱のため価電子 带の電子が 1 個霹導帯に昇ることは, 図 7 (a) の矢印の よろに原子結合に役立つために束縛されていた価電子が. 自由な空間へ放出されるという粒子モデルを当はめる が，この電子は束縛されていないので電界従って加速 され電導に関与する.さららに価電子の抜けた場所には近 い洒電子が転入でき，拔け孔のほうる移動でき同じく電 導琐象にあずかることができる・ただしこの場合には孔 が電子の運動の逆方向に動くので電気的には孔自身が正 の電荷を持ちその運動を規定する易動度 $\mu_{\boldsymbol{b}}$, したがって

*日本霓気栋式会社（川崎市下沼部 1753） 
有効質量が電導電子と異なると考えてもよいとっに正 孔の考学が出ているが，正孔はあくまで便宜上考光出さ れた概念でいずれの場合も正しいわけではなく，電子間 の相互作用のはげしい場合は不正確になる。また電導带 の電子と価電子带の正孔とは淔接をたは媒体を通して再 結合しキャリアの役目を失うことも注目して扔か稀ばな らない．たが一定の温度では統計的にある割合で電子と 正孔の密度が維持されているだけである.したがってこ のよろな場合の電導度のは（3）式*を書き直して, 電子 と正孔炕よる項で表わされねね゙ならぬ。

$$
\sigma=e \mu_{n} n+e \mu_{p} p
$$

乙か子理想結晶で法電子の密度 $n$ と正孔密度 $p$ とは等し $<$

$$
n=p=n_{i}(T)
$$

この密度は $E_{g}$ と絶刘温度の関数である.このような場 合を真性半導体と呼び， $n \neq p$ の場合の不純物半導体と 区別する。

\section{2 光 電 導}

上の説明では価電子が熱挸乱で開放されて電導性の現 われた場合を取り扱ったが， $E_{\boldsymbol{g}}$ に相当するエネルギ以 上のエネルギを持つ光量子の衡笑尤っても電子は自由 になり，自由電子一正孔対が発生する．これは $E_{g}$ と相 当する一定波長上り短加波長の光で起り，この波長を しきい值と呼んでいる. 熱擾乱の場合と異なる点流. 光 があたつた時にキャリア密度が熱平衡値より一洔的汇增 加し，光の照射をやめれば電子と正孔とが次第に再結合 して電導度が低下して熱平衡の状態にもどることであ る.

光電導は $\mathrm{CdS}, \mathrm{PbS}$ など可視光線や赤外線の検出, 測定飞利用される. 光電導は一般には光起電力（太陽電 池）などと一緒に内部光電現象と呼ばれる。一方では金 属や半導体では光の照射よるる電子の放出すなわち外部 光電效果るある. 半導体の光電現象はさらに複雑な内容 がありルネネッセンスその他光物性の名前で新しい研 究分野が開けつ」ある.

\section{3 不純物半尊体}

結晶の成分原子が規則正しく 3 次元の幾何学的配列を とった場合を理想結晶または完全結晶と呼んでいるが， こんな結晶は観念的にだけ存在するるので実在はしな いすすなら現在の結晶成長飞関する知識からしても， 何らかの幾何学的不整がないと結晶成長は起らないとと になるし，完全に不純物を含まない物賈は実在しない， これらを不完全性 (imperfection) と呼び, 幾问学的な ものと組成 (化学) 的なものとあり, 問題はこれらが結 晶の性貿とどんな影響を与光るかである．この分野のこ とはまだわたっていないことのほうが多く、わかってい るととはわずかである。

$* \sigma=e \mu_{n} n$ （前号 $\mathrm{p} .333$ 参照）

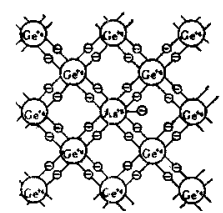

(a)

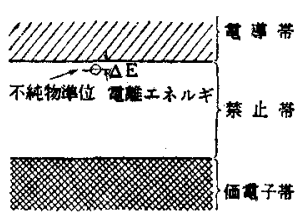

(b)
因 8 不純物半導体のモデル

そのわかっているものの1つは, Ge 江含まれる少量 のV族金属上而族金属の原子は常温でそれぞれ約 1 個の 電導電子と正孔を与兄ることでする。これは半導体の特 性の定量的説明の第一歩として非常に重要なことであ る.これを粒子モデルと帯域モデルで説明する手段とし て図 8 を用いる.粒子モデルではV族金属原子として Asを $\mathrm{Ge}$ の格子点唒置型として入れてあるが，Asは 外殼電子を5個子ち，その内 4 個は $\mathrm{Ge}^{+4}$ 之同様に隣接 $\mathrm{Ge}^{+4}$ との共有結合に利用され，残り 1 個の外款電子は $\mathrm{As}^{+5}$ 上水素原子似た形で引き合っているが，この結 合力は $\mathrm{Ge}$ 結晶中の電媒定数で薄められて非常に弱くな っている. したがって Ge 中の As は常温で添とんど $100 \%$ 電離して自由な電尊䨓子を与兄る。これは带域モ デルで図 8 (b) のように結晶中で局在したエネルギや水 準が禁止帯中に現われる形で表わされる。この準位山絶 対零度で電子が存在し, 少し温度が上ると電離して自由 電子を与えるのでドナ一準位と呼ばれ，電離エネルギ $\Delta E$ は非常に小さい.

III族不純物原子として In が入ると，その外款電子は 3 個しかなく，4 価の共有結合を形式するには 1 個不足 し，4価の共有結合をして 1 個の正孔が $\mathrm{In}^{+3}$ (目) と弱 い結合をしているのと同じと考兄られる。この正孔も容 易電離して電導性の正孔を与兄る。この不純物準位柱 価電子带のすぐ上飞局在したアクセプタ準位として表わ される.

このよろに Geなど半導体では特性の不純物が添加さ れると，不純物原子が自由電子や正孔を与えるが，こ」 で熱平衡に胡けるキャリア密度について述へよう，真性 半導体では電子密度 $n$ と正孔密度 $p$ は等しく(5) 式の上 うに温度できる一定の電子密度 $n_{i}$ に等しかったが,電 子・正孔対の発生と再結合に上る消㓕沉ては質量作 用の方則が成り立ち

$$
n \cdot p=n_{i}{ }^{2}=\text { 一定温度化つ定 }
$$

この関係は酸・アルカリの水素イオン濃度・水酸イオン 濃度の場合と同じですって，一方の濃度いかんにかりわ らず成立する。したがって不純物が一方の濃度を增加さ せれば他方の濃度は必然的飞減少する.一例として常温 $\left(300^{\circ} \mathrm{K}\right)$ と括ける平衡值 $n_{\boldsymbol{i}}$ と比抵抗 $\rho$ を示す.

$\begin{array}{lcc} & n_{i} & \rho \\ \mathrm{Ge} & 2.5 \times 10^{18} / \mathrm{cm}^{8} & 47 \Omega \mathrm{cm} \\ \mathrm{Si} & 6.8 \times 10^{10} / \mathrm{cm}^{8} & 64 \mathrm{k} \Omega \mathrm{cm}\end{array}$


(4) 式において $\mu_{n}>\mu_{p}$ であるから比抵抗の極大は真 性半導体よりアクセプタ不純物を微量添加した場合に起 るが，大まかにみてとららの種類の不純物を加光て子添 加量と有効キャリア密度とは比例する．Ge の原子密度 は $10^{22} / \mathrm{cc}$ 程度であるから $10^{-9}$ モル比以上の不純物が 入ると電導性（比抵抗）に変化を生ずる．このように半 導体の特性豆ごく徵量の不純物に対して敏感で，搆造感 性とはこのように微量な不純物や結晶の不完全性が特性 に大きな影響を写えることをいっている。

しかし以上の微量不純物が電導現象化大きい変化を与 えるのはキャリア密度の点であるが,キャリアの動きや すさを表わす易動度 $\mu$ す構造に敏感で，理想結晶の規 則正しい原子配列なら電子の進行波は何ら妨害を受けな いで温度が上って格子振動が加わると規則正しく易動度 が低下する，乙かし不純物原子があったり、格子の幾何 学的不整があれば当然電子の進行波は異常な散乱を受け 易動度は低下し，電導度は不純物のドープ量に比例せず 飽和する型になる.さらに不純物や格子不整の種類によ っては熱平衡のキャリア密度積より過鄱にキャリアのむ る場合の再結合の触媒作用をしてキャリア妾消隇する作 用をするなど複雑な構造感性を示す。このようと半導体 の電尊度 (比抵抗の逆数) は温度とともにキャりア密度 が変化し, キャリアの易動度が変化するが, ある温度以 上になると熱攪乱によって母体の価電子が谁離されその キャリア密度が不純物からのキャリア密度より優勢にな る.こうなると不純物の濃度に間題にならないで高い電 導度を持つようになり，真性半導体の電導度が不純物半 導体の電導度を追い越すので，この温度を真性温度 (in. trinsic temperature) 領域に入ったという。この温度で は当然 $p n$ 接合の特性は失われ, 整流特性やトランジス タ作用は無くなる，この温度は半導体材料特有のもので ゲルマニウムは $120^{\circ} \mathrm{C}$ 位, シリコンは $300^{\circ} \mathrm{C}$ 位, $\mathrm{GaAs}$ は $450^{\circ} \mathrm{C}$ 位で, 半導体装置の高温特性を知る目安にな る.

\section{6. 半道体の接繶}

半導体と半導体，半導体と金属の接続の電導性は非常 に複雑であるが专用的に重要であるから簡単な説明を加 えてれこう.

\section{1 表面亡整流現象}

接触整流や光起電力は半導体と金属との表面 (界面) 現象として長らく知られ，接触電位差が原团として考元 られていた。しかし亜酸化銅整流器で半導体内部之整流 性がありそうだし,Ohl などの Si 中の pn 接合の発見， Benzer の半導体同志の接触の整流性の発芫などから, 半導体が金属と接触する以前にその表面の部分に電気的 二重䙓の構造があることを考えねばならなくなった．固 体表面にこのような表面状態(エネルギ準位)が存在する
ことは古く Tamm 以来予測されていたことでるが，ゲ ルマニウム点接触ダイオードや点接触トランジスタの登 場で表面逆転風として再認識されたるのである：このよ ろな表面状繁の研究は各方面から攻撃されているが，最 近の双晶の粒子境界の遊離原子価がゲルマニウムでは $n$ 型層, シリコンでは $\boldsymbol{p}$ 型層党形成している事奏は特に点 接触素子に関係すると思われる。また $\mathrm{Ge} の$ 跨開面は $p$ 型表面層を持ち，酸化皮膜が $p$ 型原形成に重要な意味を 持つことも芫逃子ない。

\section{$6.2 \mathrm{pn}$ 接 合}

以上のように表面の接触整流8 $p n$ 接合の立場から眺 めたほうが正しいようだし，半導体の電導現象はp型で は大部分の電流が正孔で， $n$ 型では電子によって運ば れ，多数キャリアと呼ばれる. 多数キ+リアと少数キ+ りアとはその密度の積が平衡状態ては一定であるが，局 部的な平衡のやふれれ可能である程度の緩和時間を経て 平衡状態に杘ることる考光合せねばならぬから，p型と $n$ 型の両半導体が一緒に方時は正孔と電子の両方のキ ヤリアをそれぞれ独立に考皇たはうが便利である。

こうした考元方のはしめは 1938 年, 亚酸化銅整流器 を用いた半導体の整流につき提案した Davydov の pn 接合論求めるべきであるらが，多くの早すぎたアイデ ィアと同じように理論の展開と忍用を見ないで単なる歴 史的記録飞止まった. それと同しころ米国のベル研究所 では Ohl が Si の溶融精製を行ない Si の単結晶粒の 中に顕著な光電現象や整流性を示す部分のあることを見 出した.この症うは途中の進歩は遅れたが，1949年 Shockley そよって点接触トランジスタに括ける正孔注 入の説明を動機として提案されたもので，半導体工業の 驚異的発達の出発点として果用性で㢺合トランジスタ の予言をふくみ，今まで定性的だった半導体理論を完壁 な定量性まで高めた点で画期的と呼ぶ似らさわしい.

$p n$ 接合とは単結晶中で $p$ 型の部分と $n$ 型の部分とが 接続したもので，有効不純物濃度 $\left|D_{A}-D_{D}\right|$ の符号が 正から負に変化し, すなわちアクセプタ・リッチからド ナー・リッチへ変化している，したがってp型層では正 孔が多数キャリアで電子が少数キャリアであって， $n$ 型 部分は逆になる。この関係をp型のほうが比抠抗が小， すなわち高ドープな場合として図9に揭げる．接合部分 では $p=n=n_{i}$ の真性半導体の薄層（ $i$ 層）ができ, 正 孔・電子とも連続的な形を取るから電離したアタセプタ とドナーが裸になり電気的二重層ができる、これは一種 の絶縁層として働き， $p$ 型飞負， $n$ 型に正の電圧がか」 ると多数キャリアは接合部分から遠ざかって絶縁性の $i$ 層が広がって，キャリアの空乏首が広がる，この場合 $p$ 型の接合に近い部分で熱的に発生した電子と接合に近い $\boldsymbol{n}$ 型層で熱的に発生しれ正孔，これれらは少数キャリア濃 度に比例していると考光られるが，その電流だけによる 


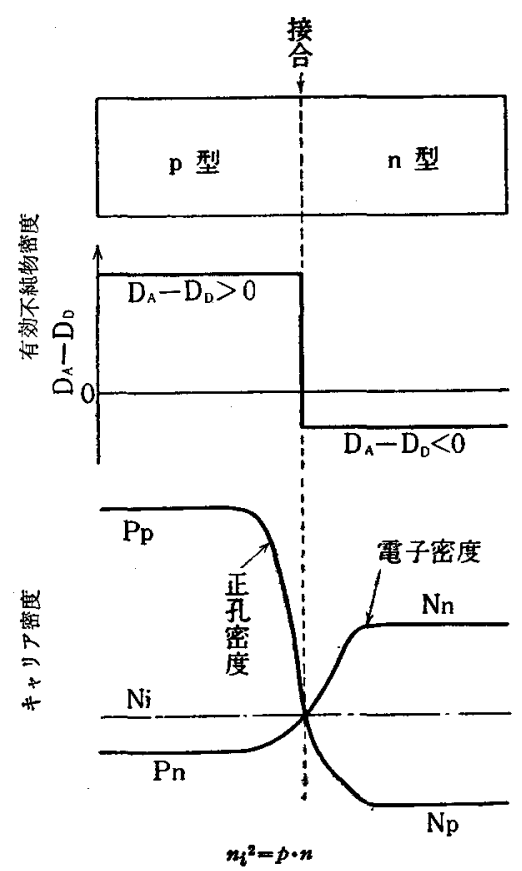

図 $9 p n$ 接合の不絉物密度とキャリフ密度 (熱平衡)
と考えられる.すなわち電圧にか」わらず飽和するので 餙和電流 Is と呼ばれる.

$$
I_{s}=e\left(D_{p} p_{n} / L_{p}+D_{n} n_{p} / L_{n}\right)
$$

逆に順方向，寸なわち $p$ 型飞正， $n$ 型飞負の電圧を加兄 ると多数キャリアが他の部分に注入されて熱平衡状態が 破れ，電流流れやすいが，多数キャリアは比抵抗の低 い部分のほうが多いので電流は当然比抵抗の低い（高口 一プ）部分の多数キャリアが最も寄与する. との場合は 電压飞依存し次式があたえられている。

$$
I=I_{s}\{\exp (e V / k T)-1\}
$$

こ」で注目すべきは, 逆電流は拡散による電流で, 拡散 定数 $D_{n}, D_{p}$ と拉散長 $L_{n}, L_{p}$ 扎よび少数キャりア密 度 $n_{p}, p_{n}$ が関係していること, 順方向電流の場合は熱 平衡の状態が破れて接合附近のキャリア密度が増加する ことである.これは少数キャリアの注入と呼ばれ，この 拡散長以内に次の $p n$ 接合が来たるのがトランジスタで ある・

半導体の電導現象については記載すべき内容が多すぎ る. 以上は代表的な共有結合半導体の電導化ついてその 一部分の現象を説明しただけである、磁性半導体，イオ ン結晶, 有機半導体など電導機構の別なもの，熱電現 象,ホール效果など現象的にも多彩な事項は割愛した. 